\title{
TRACE METALS IN LIVER AND KIDNEY OF THE FRANCISCANA (PONTOPORIA BLAINVILLEI) FROM THE NORTHERN COAST OF RIO DE JANEIRO STATE, BRAZIL
}

\author{
José Lailson-Brito Jr. ${ }^{1,2, \bullet}$, Maria Aparecida A. Azeredo ${ }^{3}$, Olaf Malm¹, \\ Renata A. Ramos ${ }^{4}$, Ana Paula M. Di Beneditto ${ }^{4}$ and Marcelo F.C. Saldanha ${ }^{5}$
}

\begin{abstract}
In the Southwestern Atlantic few studies have documented trace metal concentrations in cetacean tissues. This study presents both hepatic and renal trace metal concentrations ( $\mathrm{Fe}, \mathrm{Cu}, \mathrm{Zn}, \mathrm{Mn}, \mathrm{Hg}$ and $\mathrm{Cd}$ ), in franciscana ( $\mathrm{n}=17)$, inhabiting the waters of Rio de Janeiro State, southeastern Brazil. The concentrations of $\mathrm{Fe}, \mathrm{Cu}, \mathrm{Zn}, \mathrm{Mn}$ and $\mathrm{Hg}$ generally were highest in the liver and $\mathrm{Cd}$ levels in liver and kidney were comparable. Hepatic and renal essential metal (Fe, $\mathrm{Cu}, \mathrm{Zn}$ and $\mathrm{Mn})$ concentrations were similar to those documented elsewhere for other species. THg and $\mathrm{Cd}$ concentrations were found to increase with age. The low concentrations of trace metals determined in the franciscana tissues in this study reflect its dietary habits, trophic position and the low bioavailability of metals in northern Rio de Janeiro.

Resumo - No Atlântico Sul Ocidental poucos estudos foram desenvolvidos para a determinação das concentrações de metaistraço em tecidos de cetáceos. O presente trabalho apresenta concentrações de metais-traço $(\mathrm{Hg}, \mathrm{Cd}, \mathrm{Fe}, \mathrm{Cu}, \mathrm{Zn}$ and $\mathrm{Mn}$ ) em fígados e rins de toninhas, Pontoporia blainvillei $(\mathrm{n}=17)$ da costa norte do Estado do Rio de Janeiro. De modo geral, as concentrações mais altas de $\mathrm{Fe}, \mathrm{Cu}, \mathrm{Zn}, \mathrm{Mn}$ and $\mathrm{Hg}$ foram encontradas nos fígados e o Cd apresentou concentrações similares entre o fígado e o rim. O metais essenciais ( $\mathrm{Fe}, \mathrm{Cu}, \mathrm{Zn}$ and $\mathrm{Mn}$ ), tanto hepáticos quanto renais, apresentaram-se em concentrações similares as reportadas na literatura para outras espécies de cetáceos. Foi verificada a correlação positiva entre as concentrações de THg e $\mathrm{Cd}$ com o aumento da idade. As concentrações de metais-traço na toninha foram consideradas baixas quando comparadas com outras espécies de cetáceos. Tais resultados são reflexo dos hábitos alimentares e posição trófica da espécie, assim como da baixa biodisponibilidade dos metais analisados na costa norte do Estado do Rio de Janeiro.
\end{abstract}

Keywords: Trace metals, franciscana, Brazilian coast, western South Atlantic.

\section{Introduction}

The concentrations of some trace metals in marine mammal tissues may help to characterise the bioaccumulation and biomagnification processes throughout ecosystems (Honda et al., 1983; Muir et al., 1992; André, 1997; O'Shea, 1999). Some cetaceans are large and long-living marine predators, feeding at the top of the food chain. As such, they can integrate both temporal and spatial variations in environmental contamination (Joiris et al., 2001). In the Southwestern Atlantic few studies have documented trace metal concentrations in cetacean tissues and few peer-reviewed papers have been published in the scientific literature concerning concentrations of trace metals in the franciscana, Pontoporia blainvillei (Marchovecchio et al. 1990; 1994; Gerpe et al., 2002). In a recent review, Borrel and Aguilar (1999) identified a need for additional contaminant studies in marine mammals throughout the Central and South American regions, so as to ensure proper management of local populations and species.

The franciscana is a coastal dolphin distributed from Golfo Nuevo, Chubut Province, Argentina (Crespo et al., 1998), to Itaúnas, Espírito Santo State, Brazil (Siciliano, 1994). Along the coast of Rio de Janeiro State, Brazil, this species is found throughout the entire northern region (Di Beneditto, 1997; 2000).

Trace metal contamination of Rio de Janeiro coastal waters has been documented for some critical areas, including the north coast. Throughout this area the Paraíba do Sul River has a major influence on the alteration of physical-chemical parameters and the deposition of sediments. This river passes though Brazil's densest industrial area, throughout which industrial effluents, many containing trace metals, are released into the river (Malm et al., 1989). Trace metal concentrations, whilst high close to the discharge points, decrease toward the estuary of Paraíba do Sul River (Carvalho, 1992; Dorneles, 1993; Lacerda et al., 1993; Molisani et al., 1999).

This study presents the results of an investigation into the concentrations of trace metals $(\mathrm{Hg}, \mathrm{Cd}, \mathrm{Fe}, \mathrm{Cu}, \mathrm{Zn}$ and $\mathrm{Mn}$ ) in the liver and kidney of the franciscana, Pontoporia blainvillei, and examines the influence of biological parameters (age, total length, sex and dietary habits) on these concentrations.

\section{Material and Methods}

Samples of liver (17) and kidney (15) tissues were obtained from 17 franscicana (7 females, 10 males) incidentally captured in the gillnet fishery which has been operational in the waters off the north coast of Rio de Janeiro (Figure 1). Incidental captures of franciscanas have been reported since 1986 (Lodi et al., 1987) with an estimated 147 individuals caught in gillnets set generally in waters less than 10 nautical miles offshore between 1987 and 1996 (Di Beneditto, 1997; Di Beneditto et al., 1998).

The main characteristics of specimens are report in Table

\footnotetext{
${ }^{1}$ Laboratório de Radioisótopos E.P.F., Instituto de Biofísica Carlos Chagas Filho, UFRJ. 21941-900, Rio de Janeiro, RJ, Brazil. ${ }^{2}$ Projeto MAQUA, Depto. Oceanografia, UERJ. 20550-013, Rio de Janeiro, RJ, Brazil.

${ }^{3}$ Departamento de Química, Mestrado em Ciências Ambientais, UFRRJ. 23851-970, Seropédica, Rio de Janeiro, RJ, Brazil.

${ }^{4}$ Laboratório de Ciências Ambientais, UENF. 28015-620, Campos dos Goytacazes, RJ, Brazil.

${ }^{5}$ CNPS, EMBRAPA SOLOS. 22460-000, Rio de Janeiro, RJ, Brazil.

- Corresponding author: lailson@biof.ufrj.br.
} 


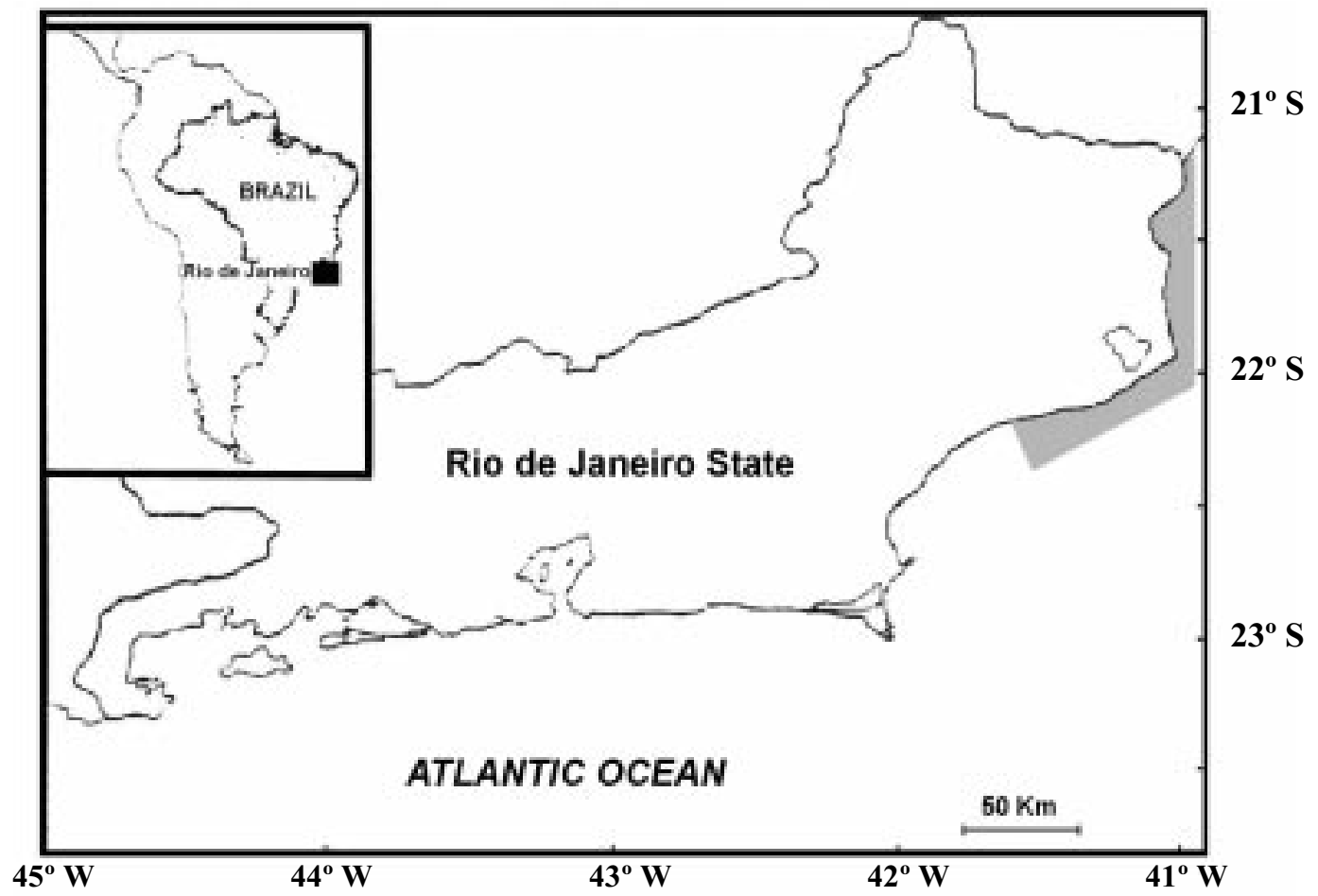

Figure 1. Rio de Janeiro State showing the sampling area along the north coast (in grey).

Table 1. Sex, size and age of the specimens analysed in this study.

\begin{tabular}{lccc}
\hline Code & Sex & Total Length $(\mathrm{cm})$ & $\begin{array}{c}\text { Age } \\
\text { (years) }\end{array}$ \\
\hline Po01 & M & 88.0 & $<1$ \\
Po02 & M & 89.0 & 1 \\
Po03 & M & 94.0 & 1 \\
Po04 & M & 94.0 & 1 \\
Po05 & M & 101.0 & 2 \\
Po06 & M & 102.5 & 2 \\
Po07 & F & 103.0 & 2 \\
Po08 & M & 107.0 & 2 \\
Po09 & M & 113.0 & 3 \\
Po10 & M & 118.0 & 3 \\
Po11 & F & 120.0 & 3 \\
Po12 & F & 130.0 & 4 \\
Po13 & M & 123.0 & 5 \\
Po14 & F & 141.0 & 6 \\
Po15 & F & 147.5 & 6 \\
Po16 & F & 138.5 & 8 \\
Po17 & F & 138.0 & 9 \\
\hline \hline
\end{tabular}

1. Morphometric measures were taken according Norris (1961) and age was estimated based on the growth layers groups (GLGs) present in the dentine and cementum of teeth (Perrin and Myrick, 1980; Ramos et al., 2000).
Samples were collected using steel knives. After dissection, all tissue samples were stored in polyethylene bags and frozen at $-20^{\circ} \mathrm{C}$, until analysis (Geraci and Lounsbury, 1993).

For total metals (Fe, Cu, Zn, Mn and $\mathrm{Cd}$ ), samples of approximately $0.5 \mathrm{~g}$ (wet $\mathrm{wt}$ ) were digested to a transparent solution with nitric acid and $\mathrm{H}_{2} \mathrm{O}_{2}$. The concentrations were then determined by ICP-AES (Optima 3000). For Total Mercury (THg), samples of approximately $0.5 \mathrm{~g}$ (wet wt) were acid-digest and determined by Cold Vapour / AAS (FIMS - Flow Injection Mercury System, Perkin Elmer) with sodium borohydride as a reducing agent. Precision and accuracy of the analytical methods were assessed by analysing standard reference material DOLT-2 (National Research Council, Canada) (Table 2).

All statistical analyses of the results were carried using Statistica 5.1 (Statsoft, Inc.).

\section{Results}

The results are summarised in Tables 3 and 4 . The concentrations of $\mathrm{Fe}, \mathrm{Cu}, \mathrm{Zn}, \mathrm{Mn}$ and $\mathrm{Hg}$ were highest in the liver and Cd levels in liver and kidney were similar.

Concentrations of all metals varied significantly between individuals. In liver samples $\mathrm{THg}$ showed the highest variability and in kidney tissues $\mathrm{Cd}$ showed the highest variability. A significant positive correlation (Spearman R) was found between total length and hepatic $\mathrm{THg}\left(\mathrm{r}_{\text {Spermann }}\right.$ $=0.74, \mathrm{p}<0.05)$, renal THg $\left(\mathrm{r}_{\text {Spermann }}=0.62, \mathrm{p}<0.05\right)$, hepatic $\mathrm{Cd}\left(\mathrm{r}_{\text {Spermann }}=0.77, \mathrm{p}<0.05\right)$, and renal Cd $(\mathrm{rs}=0.56, \mathrm{p}<$ 0.05). A negative significant correlation was verified for 
Table 2. Precision and accuracy of the analytical methods using standard material DOLT-2 (National Research Council, Canada).

\begin{tabular}{lcccccc}
\hline \hline & $\mathrm{Fe}$ & $\mathrm{Cu}$ & $\mathrm{Zn}$ & $\mathrm{Mn}$ & $\mathrm{Cd}$ & $\mathrm{Hg}$ \\
\hline \hline Our Values & $1033 \pm 83.0$ & $23.76 \pm 1.9$ & $79.10 \pm 4.4$ & $5.83 \pm 0.41$ & $18.93 \pm 1.63$ & $4.60 \pm 0.30$ \\
Certified Values & $1103 \pm 47.0$ & $25.08 \pm 1.1$ & $85.80 \pm 2.5$ & $6.88 \pm 0.56$ & $20.80 \pm 0.5$ & $4.64 \pm 0.26$ \\
\hline \hline
\end{tabular}

Table 3. Concentration ( $\mathrm{mg} \mathrm{Kg}^{-1}$ wet $\mathrm{wt}$ ) of trace metals in liver.

Table 4. Concentration ( $\mathrm{mg} \mathrm{Kg}^{-1}$ wet $\mathrm{wt}$ ) of trace metals in kidney.

\begin{tabular}{ccccccc}
\hline \hline Code & $\mathrm{Fe}$ & $\mathrm{Cu}$ & $\mathrm{Zn}$ & $\mathrm{Mn}$ & $\mathrm{Cd}$ & $\mathrm{Hg}$ \\
\hline \hline Po01 & 293 & 21 & 41 & 2.8 & 0.36 & 1.3 \\
Po02 & 501 & 8.4 & 56 & 5.2 & <D.L. & 1.3 \\
Po03 & 130 & 8.8 & 36 & 3.4 & <D.L. & 1.1 \\
Po04 & 176 & 8.1 & 25 & 2.3 & 0.42 & 1.1 \\
Po05 & 274 & 4.0 & 50 & 8.2 & $<$ D.L. & 2.4 \\
Po06 & 248 & 5.2 & 34 & 3.0 & 0.15 & 0.90 \\
Po07 & 113 & 6.4 & 28 & 3.9 & 0.24 & 2.5 \\
Po08 & 354 & 8.4 & 61 & 4.3 & 0.09 & 2.4 \\
Po09 & 364 & 5.2 & 55 & 4.6 & 0.12 & 2.3 \\
Po10 & 171 & 12 & 42 & 2.7 & 0.42 & 2.1 \\
Po11 & 227 & 7.8 & 30 & 3.6 & 0.02 & 1.9 \\
Po12 & 88 & 1.8 & 16 & 0.67 & 0.92 & 7.4 \\
Po13 & 237 & 10 & 30 & 2.4 & 1.7 & 4.3 \\
Po14 & 99 & 5.3 & 28 & 2.4 & 0.38 & 47 \\
Po15 & 83 & 4.6 & 11 & 0.45 & 0.63 & 6.9 \\
Po16 & 162 & 8.6 & 29 & 2.9 & 0.24 & 1.7 \\
Po17 & 154 & 14 & 46 & 3.9 & 0.36 & 4.7 \\
\hline \hline
\end{tabular}

\begin{tabular}{ccccccc}
\hline \hline Code & $\mathrm{Fe}$ & $\mathrm{Cu}$ & $\mathrm{Zn}$ & $\mathrm{Mn}$ & $\mathrm{Cd}$ & $\mathrm{Hg}$ \\
\hline \hline Po01 & 174 & 3.5 & 24 & 1.2 & 0.07 & 0.48 \\
Po02 & 104 & 3,0 & 18 & 0.67 & <D.L. & 0.42 \\
Po03 & 128 & 2.9 & 15 & 0.66 & 0.35 & 0.98 \\
Po04 & 173 & 4,0 & 22 & 0.59 & 0.05 & --- \\
Po05 & 167 & 1.7 & 22 & 1.2 & 0.06 & 0.98 \\
Po06 & 200 & 3.7 & 20 & 1.2 & 0.06 & 0.49 \\
Po07 & 104 & 4.3 & 14 & 0.93 & 0.12 & 1.2 \\
Po08 & --- & --- & --- & --- & --- & --- \\
Po09 & 237 & 7.3 & 34 & 0.86 & 0.40 & 1.31 \\
Po10 & 136 & 3.9 & 17 & 0.54 & 0.34 & 1.1 \\
Po11 & 157 & 4.7 & 27 & 0.63 & 0.36 & 0.80 \\
Po12 & 245 & 10 & 30 & 0.92 & 0.10 & 0.99 \\
Po13 & 103 & 1.8 & 17 & 0.79 & 0.50 & 1.3 \\
Po14 & 128 & 1.6 & 20 & 1.1 & 1.20 & 4.1 \\
Po15 & --- & --- & --- & --- & --- & 2.8 \\
Po16 & 83 & 2.5 & 11 & 0.45 & 0.63 & 3,0 \\
Po17 & 197 & 15.9 & 49 & 1.6 & 0.02 & 0.46 \\
\hline \hline
\end{tabular}

D.L. (detection limit) for $\mathrm{Cd}$ liver $=0.003 \mathrm{mg} \mathrm{Kg}^{-1}$ wet wt

D.L. (detection limit) for Cd kidney $=0.002 \mathrm{mg} \mathrm{Kg}^{-1}$ wet wt. Dash lines indicate not analysed samples.

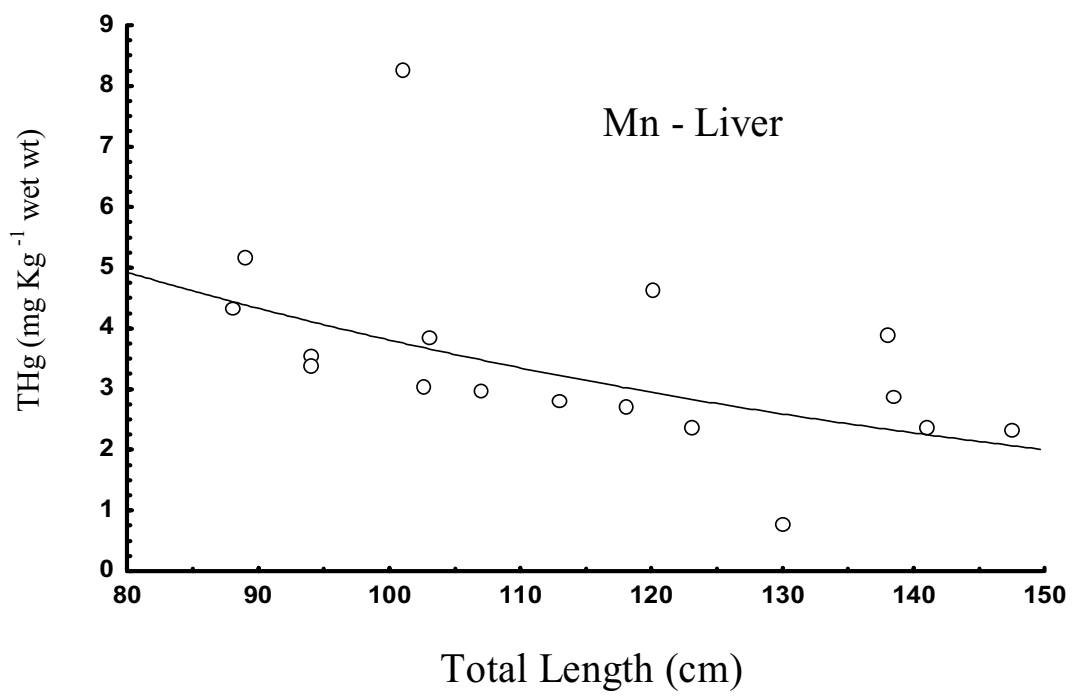

Figure 2. Mn concentrations ( $\mathrm{mg} \mathrm{Kg}^{-1}$ wet $\mathrm{wt}$ ) versus total length $(\mathrm{cm})$ in liver. 

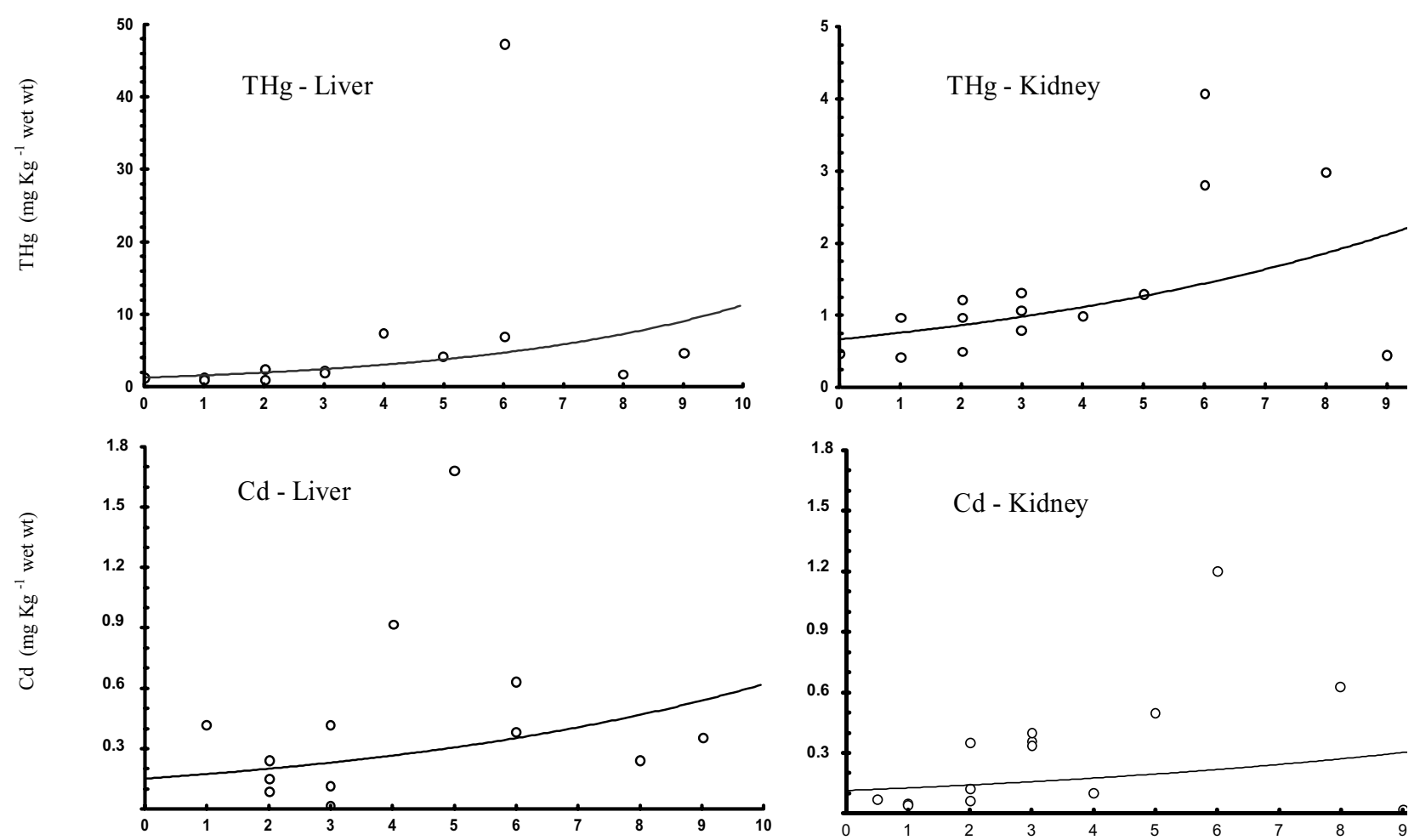

Age (years)

Figure 3. $\mathrm{THg}$ and $\mathrm{Cd}$ concentrations ( $\mathrm{mg} \mathrm{Kg}^{-1}$ wet $\mathrm{wt}$ ) versus age (years) in liver and kidney.

hepatic Mn $\left(\mathrm{r}_{\text {Spermann }}=-0.66, \mathrm{p}<0.005\right)$ (Figure 2). The correlation between age and metal concentration was significant for hepatic $\mathrm{THg}\left(\mathrm{r}_{\text {Spermann }}=0.69, \mathrm{p}<0.05\right)$, renal $\mathrm{THg}\left(\mathrm{r}_{\text {Spermann }}=0.54, \mathrm{p}<0.05\right)$ and hepatic Cd $\left(\mathrm{r}_{\text {Spermann }}=\right.$ $0.77, \mathrm{p}<0.005)$. THg and Cd concentrations versus age are present in Figure 3. The differences of metal concentrations between males and females were not significant $(p>0.05$, Mann-Whitney U test).

\section{Discussion}

Iron

Iron is found naturally in mammals as a component of the molecular structure of hemoglobin and as a result, iron concentrations are normally high in marine mammals (Mackey et al., 1995; Bowles, 1999). The highest concentrations of Fe were found in the liver. This result reflects the accumulation of Fe in hemosyderin and ferrytin. In general the concentrations obtained were similar to those reported for other cetacean species (Fujise et al., 1988; Honda et al., 1983; Kannan et al., 1993).

\section{Copper}

Copper is an essential element, being very important for the function of several enzymatic systems of mammals, and is regulated by metabolic processes (Zeisler et al., 1993; Mackey et al., 1995). The highest concentration of
Cu was found in the neonate's liver Po01 (21 $\mathrm{mg} \mathrm{Kg}^{-1}$ wet $w t)$. In most species of mammals, liver $\mathrm{Cu}$ concentrations tend to decrease with age being higher in foetus and neonate liver tissue than in adults (Underwood, 1971; Law, 1996). Venugopal and Luckey (1978) reported that livers of newborn animals are rich in cystine, a protein linked to $\mathrm{Cu}$, which has a detoxifying or storage function. Mammalian milk generally contains low concentrations of $\mathrm{Cu}$ and is not regarded as a primary source of copper in neonates. Consequently, $\mathrm{Cu}$ concentrations in neonates can be considered to represent $\mathrm{Cu}$ assimilated during gestation. Wood and Van Vleet (1996) suggested that concentrations of copper decrease during the first year of life and are followed by the maintenance of fairly constant concentrations throughout an animal's life. This pattern has been found in cetaceans elsewhere (Law et al., 1992). However, this is not clear in the franciscana, perhaps due to the low number of neonates, and absence of foetuses in our study.

\section{Zinc}

Zinc is an essential element which is necessary to maintain the integrity of the immune system and also participates in a number of other biological processes. Law et al. (1991) hypothesised that cetaceans could regulate hepatic $\mathrm{Zn}$ concentrations within the range $20-100 \mathrm{mg} \mathrm{Kg}^{-1}$ wet wt approximately, similar to those concentrations found in another mammals, including man (Hambidge et al., 1986). 
The concentrations showed to be more homogeneous in kidneys than in livers of franciscanas.

Concentrations of hepatic $\mathrm{Zn}$ in the franscicana presented here $\left(11-61 \mathrm{mg} \mathrm{Kg}^{-1}\right.$ wet $\left.\mathrm{wt}\right)$ were similar to the range proposed by Law et al. (1991). Such concentrations are lower than that found in the franciscana previously $\left(83 \pm 40 \mathrm{mg} \mathrm{Kg}^{-1}\right.$ wet wt), and those found in the pygmy sperm whale Kogia breviceps, (162 $\mathrm{mg} \mathrm{Kg}^{-1}$ wet wt) (Marcovecchio et al., 1990) and the marine tucuxi, Sotalia fluviatilis (126 $\mathrm{mg} \mathrm{Kg}^{-1}$ wet wt) (Lailson-Brito, 2000) from the Southwestern Atlantic area.

Neither hepatic nor renal Zn were significantly correlated to age in the franciscana in this study, although this has been the case for other species (Falconer et al., 1983; Caurant et al., 1994). The renal Zn concentrations of the fransciscana presented here $\left(11-49 \mathrm{mg} \mathrm{Kg}^{-1}\right.$ wet wt) were lower than those reported previously $\left(79 \pm 21 \mathrm{mg} \mathrm{Kg}^{-1}\right.$ wet wt) (Marcovecchio et al., 1990), but similar to those found in the marine tucuxi $\left(13-33 \mathrm{mg} \mathrm{Kg}^{-1}\right.$ wet $\left.\mathrm{wt}\right)$ from the North coast of Rio de Janeiro (Lailson-Brito, 2000). This finding may be related to the low bioavailability of metals in the Rio de Janeiro coast, as suggest by Lacerda et al. (1986).

\section{Manganese}

Whilst there have been very few studies in which concentrations of Mn have been determined in marine mammals, concentrations in all types of tissues have been less than $7 \mathrm{mg} \mathrm{Kg}^{-1}$ wet wt (Thompson, 1990; Mackey et al., 1995). Concentrations of Mn found in this study were higher in the liver than kidney, corroborating the pattern reported in others studies (Honda et al., 1982; 1983; Fujise et al., 1988; Szefer et al., 1994; Mackey et al., 1995).

\section{Cadmium}

The concentrations of both hepatic and renal $\mathrm{Cd}$ found in the franciscana in this study were low, as for another coastal dolphin, the marine tucuxi, from the Rio de Janeiro coast (Lailson-Brito et al., 2000). The coastal dolphins of Rio de Janeiro ingest low concentrations of $\mathrm{Cd}$, due to the low availability of this metal in the environment and, consequently, low transfer in the local marine food web. The main source of $\mathrm{Cd}$ is via dietary intake and varies according to prey species consumed (Law et al., 1992; Reijnders, 1996). Squids have, naturally, high concentrations of this metal (Bustamante et al., 1998). In the franciscana, as a result of its precocious feeding on solids, very young individuals can show trace concentrations of $\mathrm{Cd}$, which then increase quickly. On the North coast of Rio de Janeiro, solid food was found in the stomach of a male franciscana only two months old (Di Beneditto, 1997).

The positive correlation between Cd concentration and total length observed in this study is similar to that documented in other species such as striped dolphins, Stenella coeruleoalba (Honda et al., 1982), long-finned pilot whales, Globicephala melas (Caurant et al., 1994) and the pantropical spotted dolphin, Stenella attenuata (André et al., 1990; Meador et al., 1993). However, no significant correlation was observed between age and renal $\mathrm{Cd}$ concentration. It was expected that older individuals presented higher concentrations, but two franciscanas aged 8 (Po16) and 9 years (Po17) shows low renal $\mathrm{Cd}$ concentrations. The fransciscana has a relatively short life cycle with a maximum life-span of between 15 and 21 years (Kasuya and Brownell, 1979; Pinedo and Hohn, 2000). Lower concentrations in older individuals may suggest that the concentrations of renal $\mathrm{Cd}$ begin to decrease with senescence. Yamamoto et al. (1985) reported a fall in $\mathrm{Cd}$ concentrations in the minke whale with the start of senescence.

\section{Mercury}

Mercury's toxic effects on wildlife have long been recognised, and many cetaceans have a very high $\mathrm{Hg}$ accumulative capacity as they absorb $\mathrm{Hg}$ in organic form from their fish prey (Augier et al., 1993; Wagemann et al., 1998; Bowles, 1999). THg concentrations in the franciscana tissues analysed here were higher than those previously documented for this species (liver: $3.8 \pm 1.2$, kidney: $1.9 \pm 0.7 \mathrm{mg} \mathrm{Kg}^{-1}$ wet wt) (Marchovecchio et al., 1990). However, the concentrations reported by Marchovecchio et al. (1990) were derived from only three animals and all were younger than 3 years old. As $\mathrm{Hg}$ can accumulate with age, this lack of older animals would skew the average concentrations to lower values. The highest concentrations reported in cetacean tissues from South America were $86 \pm 7.3 \mathrm{mg} \mathrm{Kg}^{-1}$ wet $\mathrm{wt}$, in the liver tissues of two bottlenose dolphins from Argentina (Marcovecchio et al., 1990). Recently, analyses of marine tucuxi from Guanabara Bay, Rio de Janeiro State, have also revealed high hepatic concentrations, with one specimen containing $133 \mathrm{mg} \mathrm{Kg}^{-1}$ wet wt (Lailson-Brito et al., in press). $\mathrm{THg}$ tends to increase with age in marine mammal liver and kidney tissues (O'Shea, 1999), and the franciscanas studied here showed a similar pattern (Figure 2 and Figure 3), and the concentrations of $\mathrm{THg}$ increase rapidly with increasing age. However, they are relatively low in comparison to those documented elsewhere for other species (André et al., 1991; Augier et al., 1993; Caurant et al., 1994; Wagemann et al., 1998; Bowles, 1999).

Mercury is known to cross the marine mammal placenta and is also transferred during lactation (Wagemann et al., 1988; Law, 1996). The neonate Po01 contained THg concentrations of $1.3 \mathrm{mg} \mathrm{Kg}^{-1}$ wet wt, in liver, and $0.48 \mathrm{mg}$ $\mathrm{Kg}^{-1}$ wet wt, in kidney. In Rio de Janeiro State, very young specimens ( $<1$ year) feed on solids and our results could be due to a group of factors: transplacental transfer, transfer during lactation and early ingestion of contaminated food. Marine mammals take up contaminants mainly via ingested prey (Reijnders, 1996). Franciscanas feed preferably on small fish and squid in Rio de Janeiro coastal waters (Di Beneditto, 2000). Mercury in fish prey is generally in the toxic organic form but, in spite of the high concentrations of mercury present in the 
liver of marine mammals, toxic effects have not been reported. The absence of toxic effects is probably related to a slow detoxification mechanism, in which methylmercury is demethylated and deposited as inert mercuric selenide in the liver of marine mammals (Palmisano et al., 1995; Holsbeek et al., 1999).

\section{General}

The low concentrations of trace metals determined in the franciscana tissues in this study reflect it's dietary habits in the northern Rio de Janeiro State area. Franciscana fed mainly on small fish and cephalopods, as result of anatomical characteristics (Di Beneditto, 2000). The low metal concentrations observed are also related to their trophic position (low trophic level) and the low bioavailability of metals in the local marine environment. Studies focusing on the flow of metals throughout the franciscana's food chain are essential in characterising metal dynamics and uptake.

Further studies focusing on organic compounds, such as the DDTs, PCBs, TBTs and methylmercury, and those with larger sample sizes, including other franciscana populations, are urgently required for a better understanding of the significance of contaminant accumulation in this species throughout its life cycle.

\section{Acknowledgements}

We thank the referees Robin J. Law, Claude R. Joiris, Karen Evans, Claudio Leonzio and the Editor for providing constructive comments to this manuscript. We thank Izabel Gurgel, Marcos A. Fernandez and Friedrich Herms, of Universidade Estadual do Rio de Janeiro, for logistical and laboratorial support. Haydée Cunha reviewed the early drafts of the manuscript. Viviane Escaleira, Marcos Paulo Soares and Orjana Silva for their assistance in laboratorial analyses. Laerte Azeredo, Alexandre Azevedo, Ana B. Fragoso and Vanessa L. Teixeira for their help and enthusiasm. Lailson-Brito is supported by CAPES.

\section{References}

André, J.M. (1997) Problematic and methodological approach of the study of the bioaccumulation of trace elements in delphinids. Pages 39-50 in Jauniaux, T., Bouquegneau, J.M. and Coignoul, F. (Eds) Marine Mammals, Seabirds, and Pollution of Marine Systems. Presses Fac. Médecine Vétérinaire de l'Université de Liège, Liège.

André, J.M., Amiard-Triquet, C., Boudou, A., Amiard, J.C. and Ribeyre, F. (1990) Cadmium contamination of tissues and organs of delphinid species (Stenella attenuata) - influence of biological and ecological factors. Ecotoxicology and Environmental Safety 20: 290-306.

André, J., Boudou, A., Ribeyre, F. and Bernhard, M. (1991) Comparative study of mercury accumulation in dolphins (Stenella coeruleoalba) from French Atlantic and Mediterranean coasts. Science of the Total Environment 104: 191-209.

Augier, H., Park, W.K. and Ronneau, C. (1993) Mercury contamination of the striped dolphin Stenella coeruleoalba meyen from the French Mediterranean Coasts. Marine Pollution Bulletin 26: 306-311.

Borrel, A. and Aguilar, A. (1999) A review of organochlorine and metal pollutants in marine mammals from Central and South America. Journal Cetacean Research Management (Special Issue 1): 195-207.

Bowles, D. (1999) An overview of the concentrations and effects of metals in cetacean species. Journal Cetacean Research Management (Special Issue 1): 125-148.

Bustamante, P., Caurant, F., Fowler, S.W. and Miramand, P. (1998) Cephalopds as a vector for the transfer of cadmium to top marine predators in the north-east Atlantic Ocean. Science of the Total Environment 220: 71-80.

Carvalho, C.E.V. (1992) Distribuição de metais pesados em sedimentos da plataforma continental nordeste e sudeste do Brasil. MSc Thesis. CEG, Instituto de Química, Universidade Federal Fluminense, Niterói. 91pp.

Caurant, F., Amiard, C., Amiard-Triquet, C. and Sauriau, P.G. (1994) Ecological and biological factors controlling the concentrations of trace elements (As, $\mathrm{Cd}, \mathrm{Cu}, \mathrm{Hg}$, Se, $\mathrm{Zn}$ ) in delphinids Globicephala melas from the North Atlantic Ocean. Marine Ecology Progress Series 103: 207-219.

Crespo, E.A., Harris, G. and González, R. (1998) Group size and distributional range of the franciscana, Pontoporia blainvillei. Marine Mammal Science 14: 845-849.

Di Beneditto, A.P. (1997) Captura de pequenos cetáceos em rede de espera: uma ameaça às populações do Norte do Rio de Janeiro? MSc Thesis. Ciências Ambientais, Universidade Estadual do Norte Fluminense, Campos dos Goytacazes. 91pp.

Di Beneditto, A.P. (2000) Ecologia alimentar de Pontoporia blainvillei e Sotalia fluviatilis (Cetacea) na costa norte do estado do Rio de Janeiro, Brasil. PhD Thesis. Universidade Estadual do Norte Fluminense, Campos dos Goytacazes. 128pp.

Di Beneditto, A.P., Ramos, R. and Lima, N.R.W. (1998) Fishing activity in Northern Rio de Janeiro State (Brazil) and relation with small cetaceans. Brazilian Archives of Biology and Technology 41: 296-302.

Dorneles, L.M.A. (1993) Metais pesados na plataforma continental entre Ilha Grande e Cabo Frio (RJ) e suas associações com a granulometria, conteúdo de carbonato e matéria orgânica. CEG, Instituto de Química, Universidade Federal Fluminense. Niterói. 155pp.

Falconer, C.R., Davies, I.M. and Topping, G. (1983) Trace metals in the common porpoise, Phocoena phocoena. Marine Environmental Research 8: 119-127.

Fujise, Y., Honda, K., Tatsukawa, R. and Mishima, S. (1988) Tissue distribution of heavy metals in Dall's porpoise in the Nothwestern Pacific. Marine Pollution Bulletin 19: 226-230.

Geraci, J.R. and Lounsbury, V.J. (1993) Marine Mammals Ashore. A field Guide for Strandings. Texas A\&M Sea Grant.

Gerpe, M., Rodríguez, D., Moreno, V.J., Bastida, R.O. and de Moreno, J.E. (2002) Accumulation of heavy metals in the franciscana (Pontoporia blainvillei) from Provincia Buenos Aires, Argentina. The Latin American Journal of Aquatic Mammals (special issue) 1: 95-106.

Hambidge, K.M., Casey, C.E., Krebs, N.F. (1986) Zinc. Pages 1-137 in Mertz, W. (Ed.) Trace elements in human and animal nutrition. $5^{\text {th }}$ ed., v. 2. Academic Press, Orlando.

Holsbeek, L., Joiris, C.R., Debacker, V., Ali, I.B., Roose, P., Nellissen, J.P., Gobert, S., Bouquegneau, J.M. and Bossicart, M. (1999) Heavy metals, Organochlorines and Polycyclic Aromatic Hydrocarbons in sperm whales stranded in the Southern North Sea During the 1994/1995 winter. Marine Pollution Bulletin 38: 304-313.

Honda, K., Tatsukawa, R. and Fujiyama, T. (1982) Distribution characteristics of heavy metals in the organs and tissues of 
striped dolphin, Stenella coeruleoalba. Agricultural Biology Chemistry 46: 3011-13121.

Honda, K., Tatsukawa, R., Itano, K., Miyazaki, N. and Fujiyama, T. (1983) Heavy metal concentrations in muscle, liver and kidney tissue of striped dolphin, Stenella coeruleoalba, and their variations with body length, wt, age and sex. Agricultural Biology Chemistry 47: 1219-1228.

Joiris, C.R., Holsbeek, L., Bolba, D., Gascard, C., Stanev, T., Komakhidzes, A., Baumgärten, W. and Birkun, A. (2001) Total and organic mercury in the Black Sea harbour porpoise Phocoena phocoena relicta. Marine Pollution Bulletin 42: 905-911.

Kannan, K., Sinha, R.K., Tanabe, S., Ichihashi, H. and Tatsukawa, R. (1993) Heavy metals and Orgnochlorine Residues in Ganges River Dolphins from India. Marine Pollution Bulletin 26: 159-162.

Kasuya, T. and Brownell, R.L. (1979) Age determination, reproduction and growth of franciscana dolphin, Pontoporia blainvillei. Scientific Reports of the Whales Research Institute 31: 45-67.

Lacerda, L.D., Rezende, C.E., José, D.M.V. and Francisco, M.C.F. (1986) Metalic composition of mangrove leaves from the Southeastern Brazilian coast. Revista Brasileira de Biologia, 46(2): 395-399.

Lacerda, L.D., Carvalho, C.E.V., Rezende, C.E. and Pfeiffer, W.C. (1993) Mercury in sediments from the Paraíba do Sul River continental shelf, S.E. Brazil. Marine Pollution Bulletin 23: 107-116.

Lailson-Brito Jr., J. (2000) Estudo ecotoxicológico de metais-traço (Fe, $\mathrm{Cu}, \mathrm{Zn}, \mathrm{Mn}$, Cde Pb) em cetáceos da costa do estado do Rio de Janeiro. MSc Thesis. Universidade Federal Rural do Rio de Janeiro, Seropédica. 107pp.

Lailson-Brito Jr., J., Azeredo, M.A.A., Saldanha, M.F.C., Fernandez, M.A. and Herms, F. (2000) Estudo Ecotoxicológico das concentrações de cádmio em tecidos de golfinhos (Cetacea, Delphinidae) de hábitos costeiros e oceânicos, de águas do Estado do Rio de Janeiro. Pages 183-197 in Espíndola, E.L.G., Paschoal, C.M.R.B., Rocha, O., Bohrer, M.B.C. and Neto A.L.O. (Eds) Ecotoxicologia: Perspectivas para o Século XXI. Editora RIMA, São Carlos.

Lailson-Brito, J., Kehrig, H.A. and Malm, O. (in press) Mercúrio total nos tecidos do boto-cinza, Sotalia fluviatilis (Cetacea, Delphinidae), da Baía de Guanabara, Rio de Janeiro, Rio de Janeiro in Prego, R., Duarte, A., Panteleitchouk, A.V., Santos, T.R. (Eds) Estudos sobre Contaminação Ambiental na Península Ibérica. Editora Piaget, Viseu.

Law, R.J. (1996) Metals in Marine Mammals. Pages 357-76 in Beyer, W.N., Heinz, G.H., Redmon-Norwood, A.W. and Redman, A.W. (Eds) Environmental Contaminants in Wildlife: Interpreting Tissue Concentrations. CRC Press, Inc., Boca Raton.

Law, R.J., Fileman, C.F., Hopkins, A.D., Baker, J.R., Harwood, J., Jacksons, D.B., Kennedy, S., Martin, A.R. and Morris, R.J. (1991) Concentrations of trace metals in the livers of marine mammals (seals, porpoises and dolphins) from waters arround the British Isles. Marine Pollution Bulletin 22: 183-191.

Law, R.J., Jones, B.R., Baker, J.R. Kennedy, S, Milne, R. and Morris, R.J. (1992) Trace metals in the livers of marine mammals from the Welsh coast and the Irish Sea. Marine Pollution Bulletin 24: 296-304

Lodi, L., Siciliano, S. and Capistrano, L. (1987) Primeiro registro de Pontoporia blainvillei (Cetacea, Platanistoidea) no litoral Norte do Estado do Rio de Janeiro. Pages 69-70 in Anais, II Reunião de Trabalho de Mamíferos Aquáticos da América do Sul, Rio de Janeiro.

Mackey, E.A., Demiralp, R., Becker, P.R., Greenberg, R.R., Koster, B.J. and Wise, S.A. (1995) Trace element concentrations in cetacean liver tissues archived in the National Marine Mammal
Tissue Bank. Science of the Total Environment 175: 25-41.

Malm, O., Pfeiffer, W.C., Fiszman, M. and Azcue, J.M.P. (1989) Heavy metal concentrations and availability in the bottom sediments of the Paraíba do Sul - Guandu river system, RJ, Brasil. Environmental Technology Letters 10: 675-680.

Marcovecchio, J.E., Moreno, V.J., Bastida, R.O., Gerpe, M.S. and Rodríguez, D.H. (1990) Tissue distribution of heavy metals in small cetaceans from the Southwestern Atlantic Ocean. Marine Pollution Bulletin 21: 299-304.

Marcovecchio, J.E., Gerpe, M.S., Bastida, R.O., Rodríguez, D.H. and Morón, S.G. (1994) Environment contamination and marine mammals in coastal waters from Argentina: an overview. Science of the Total Environment 154: 141-151.

Meador, J.P., Varanasi, U., Robisch, P.A. and Chan, S.L. (1993) Toxic metals in pilot whales (Globicephala melaena) from strandings in 1986 and 1990 on Cape Cod, Massachusetts. Canadian Journal Fisheries Aquatic Science 50: 2698-706

Molisani, M.M., Salomão, M.S.M.B., Ovalle, A.R.C., Rezende, C.E., Lacerda, L.D. and Carvalho, C.E.V. (1999) Heavy metals in sediments of the lower Paraíba do Sul River, R.J., Brazil. Bulletin Environment Contaminantion Toxicology 63: 682-690.

Muir, D.C.G., Wagemann, R., Hargrave, B.T., Thomas, D.J., Peakall, D.B. and Nostrom, R.J. (1992) Artic marine ecosystem contamination. Science of the Total Environment 122: 75-134.

Norris, K.S. (Ed.) (1961) Standardized methods for measuring and recording data on the smaller cetaceans. Journal of Mammalogy 42(4): 471-476.

O'Shea, T.J. (1999) Environmental contaminants and marine mammals. Pages 485-563 in Reynolds III, J.E. and Rommel, S.A. (Eds) Biology of marine mammals. Smithsonian Institution Press, Washington.

Palmisano, F., Cardellichio, N. and Zambonin, P.G. (1995) Speciation of mercury in dolphin liver: a two-stage mechanism for the demethylation accumulation process and role of selenium. Marine Environmental Research 40: 109-121.

Perrin, W.F. and Myrick Jr., A.C. (Eds) (1980) Age determination of toothed whales and sirenians. International Whaling Commission (special issue 3), Cambridge.

Pinedo, M.C. and Hohn, A. (2000) Growth layer patterns in teeth from the franciscana, Pontoporia blainvillei: developing a model for precision in age estimation. Marine Mammal Science 16: 1-27.

Ramos, R., Di Beneditto, A.P. and Lima, N.R.W. (2000) Relationship between morphology, sex, body length and age in Pontoporia blainvillei and Sotalia fluviatilis (Cetacea) in Northern Rio de Janeiro, Brazil. Revista Brasileira de Biologia 60: 283-290.

Reijnders, P.J.H. (1996) Organohalogen and heavy metal contamination in cetaceans: observed effects, potential impact and future prospects. Pages 205-217 in Simmonds, M.S. and Hutchinson, J.D. (Eds) The conservation of whales and dolphins: science and practice. John Wiley and Sons Ed., New York.

Siciliano, S. (1994) Review of small cetaceans and fishery interactions in coastal waters of Brazil. Pages 241-250 in Perrin, W.F., Donavan, G.P. and Barlow, J. (Eds) Cetaceans and gillnets. Report International Whaling Commission (Special Issue 15), Cambridge.

Szefer, P., Malinga, M., Sköra, K. and Pempkowiak, J. (1994) Heavy metals in harbour porpoises from Puck Harbour in the Baltic Sea. Marine Pollution Bulletin 28: 570-571.

Thompson, P.M. (1990) Metal levels in marine vertebrates. Pages 143-182 in Furness, R.W. and Rainbow, P.S. (Eds) Heavy metals in the marine environment. CRS Press, Boca Raton.

Underwood, E.J. (1971) Trace elements in human and animal nutrition. Academic Press, New York. 
Venugopal, B. and Luckey, T.D. (Eds) (1978) Metal toxicity in mammals. 2. Metal toxicity of metals and metalloids. Plenum Press, New York. Wagemann, R., Stewart, R.E.A., Lockhart, W.L., Stewart, B.E. and Povoledo, M. (1988) Trace metals and methyl mercury: Associations and transfer in harp seal (Phoca groenlandica) mothers and pups. Marine Mammal Science 4: 339-355.

Wagemann, R., Trebacz, E., Boila, G. and Lockhart, W.L. (1998) Methylmercury and total mercury in tissues of Artic marine mammals. Science of the Total Environment 218: 19-31.

Wood, C.M. and Van Vleet, E.S. (1996) Copper, cadmium and zinc in liver, kidney and muscle tissues of bottlenose dolphins (Tursiops truncatus) stranded in Florida. Marine Pollution Bulletin 32: 886-889.

Yamamoto, Y., Honda, K. and Tatsukawa, R. (1985) Recent acceleration of cadmium and mercury accumulations and possible occurrence of renal dysfunction in southern Minke whales. Pages 425-428 in Proceedings, International Conference of Heavy Metals in the Environment, V.1, Atens.

Zeisler, R., Demiralp, R., Koster, B.J., Becker, P.R., Burow, M., Ostapczuk, P. and Wise, S.A. (1993) Determination of inorganic constituents in marine mammal tissues. Science of the Total Environment 139/140: 365-386. 